Keywords: ANN

Artificial intelligence

Dendrometry

Historic: Received 20/04/2017 Accepted 04/12/20 17

Palavras chave: RNA Inteligência artificial Dendrometria

+Correspondence: cabacinha@ufmg.br

DOI:
Talles Hudson Souza Lacerda', Christian Dias Cabacinha ${ }^{2+}$, Carlos Alberto Araújo Júnior ${ }^{2}$, Renato Dourado Maia ${ }^{3}$, Klaus Wesley de Souza Lacerda'

\section{ARTIFICIAL NEURAL NETWORKS FOR ESTIMATING TREE VOLUME IN THE BRAZILIAN SAVANNA}

ABSTRACT: This paper seeks to estimate tree volumes of different species from the Brazilian savanna by using artificial neural networks and by making comparisons of results with estimates obtained from traditional volumetric equations. Data was obtained from 15 squared samples of $400 \mathrm{~m}^{2}$ in an area of 29.6 ha. In each plot, breast height diameter (D) (diameter at $1.30 \mathrm{~m}$ from soil), total height $(\mathrm{Ht})$ and commercial height $(\mathrm{Hc})$ of all individuals with $D$ equals or higher than $3.0 \mathrm{~cm}$ were measured. Afterwards, each tree was felled for volume measurement. Huber method was used considering measurement of stem diameters with more than $3.0 \mathrm{~cm}$. Obtained data was used to train artificial neural networks (ANN) and to adjust volumetric equations to estimate total and commercial volume of trees. This study has shown that ANN and regression models are efficient for obtaining estimated volumes of trees in the Brazilian savanna. This suggests that artificial neural networks, that take into consideration species as a categorical input variable and were data trained, presented better results than those that are trained without categorical input.

\section{REDES NEURAIS ARTIFICIAIS PARA ESTIMAR O VOLUME DE ÁRVORES NO CERRADO}

RESUMO: Neste artigo buscou-se estimar os volumes de árvores de diferentes espécies do Cerrado usando redes neurais artificiais e fazer comparações dos resultados com estimativas obtidas a partir de equações volumétricas tradicionais. Os dados foram coletados em 15 parcelas de $400 \mathrm{~m}^{2}$ em uma área de 29,6 ha. Em cada parcela, o diâmetro da altura do peito (D) (diâmetro a I,30 m do solo), a altura total $(\mathrm{Ht})$ e a altura comercial $(\mathrm{Hc})$ de todos os indivíduos com $D$ igual ou superior a $3,0 \mathrm{~cm}$ foram medidos. Depois, cada árvore foi derrubada para obtenção do volume. $O$ método de Huber foi usado considerando a medida dos diâmetros do fuste até $3,0 \mathrm{~cm}$. Os dados obtidos foram utilizados para treinar redes neurais artificiais (RNA) e ajustar equações volumétricas para estimar o volume total e comercial das árvores. Este estudo mostrou que as RNA e as equações volumétricas são eficientes para a obtenção de volumes estimados de árvores no Cerrado. As redes neurais artificiais, que consideram a espécie como uma variável categórica de entrada, apresentaram melhores resultados do que aquelas que são treinadas sem essa variável. 


\section{INTRODUCTION}

The Brazilian biome known as Cerrado (the Brazilian savanna) has a great diversity of habitats and species with predominance of trees and shrubs (KLINK; MACHADO, 2005). Tree species usually have irregular shaped stems with a thick bark, medium height and it is the biggest biome in the state of Minas Gerais (RUFINI et al., 20I0). Unfortunately, this type of vegetation has been degraded by human activity such as livestock and urbanization.

Some studies describing the floristic richness and horizontal structure in the Brazilian savanna were performed for knowledge and preservation, however, few of them were focused in volume and biomass variables (REZENDE et al., 2006). A possible explanation for data scarcity might be attributed to the high diversity of species, high variability among individuals from the same species and the irregular shape of stems and canopy.

Tree volume is obtained by measuring diameters in different sections of a stem. Then, volume is used to adjust regression equations that explain tree volume in function of height and diameter at breast height. Parameters of these equations can be influenced by stem shape ( $\mathrm{HUSCH}$ et al., 2002), which can be problematic for Brazilian savanna trees. Problems on modelling relationships between dendrometric variables are not exclusive of natural forests. The existence of complex and nonlinear relationships may occur in several cases when it comes to studies involving natural resources, and the adjustment of equations that aim to find data tendency may be difficult (SOARES, 20I2). The use of artificial neural networks (ANN) have been proposed to solve these nonlinear and complex problems (VAHED, 2016; NUNES; GORGENS, 2016; MIGUEL et al., 2016; CAMPOS et al., 2016; SOARES et al., 20ll; SILVA et al., 2009; LIMA et al. 2017).

ANN is a system composed by simple units that are determined by mathematical functions massively processed in a parallel way (BRAGA et al., 2000; HAYKIN, 2009). These systems can learn from examples and can generalize knowledge of unknown data (JAIN et al., 1996; BRAGA et al., 2000; GORGENS et al., 2009). ANN is inspired by the human brain and its units (artificial neurons) are arranged in one or more layers, with connections (weights) between each other (BRAGA et al., 2000).

This computational tool has several uses in forestry, as techniques for biometry and forest inventory that improve accuracy in production estimation (SILVA et al., 2009). ANN presented best performances running classic regression models that are used to estimate tree volumes. These results seem to suggest that due to their massive structure and parallel distribution (layers) neural networks have the ability to learn and generalize, which make them capable of solving complex problems. They are noise tolerant, can model several variables and their non-linear relationships, they are capable of modeling with categorical (qualitative) variables in addition to numerical (quantitative) variables and can make neurobiological analogies (BINOTI, 20I3; HAYKIN, 200I). However, these applications are mostly performed with evenaged forest data, approaches with uneven-aged data are infrequent, especially in the Brazilian savanna. Tree counting performed by non-destructive methods is impractical due to the specific shape of the trees. Volume estimates are often performed with equations that generate estimates of volume with low precision.

The hypothesis to be tested in this study is that the application of ANN will increase accuracy of tree volume estimates, and reduce costs with forest inventory and cubage. The main aims of this research project have therefore been to demonstrate that the use artificial neural networks can be a tool to estimate the volume of trees from different species of the Brazilian savanna and to make a comparison of these estimates with volumetric equations generated by other methods.

\section{MATERIAL AND METHODS}

\section{Study area and data}

Data was obtained from 15 squared samples with $400 \mathrm{~m}^{2}$ in a Brazilian savanna area with 29.6 ha. In each plot, breast height diameter (D) (diameter at I,30 m from soil) and height $(\mathrm{H})$, both total $(\mathrm{Ht})$ and commercial $(\mathrm{Hc})$ height, of all individuals with $D$ equals or higher than $3,0 \mathrm{~cm}$ were measured, with them being identified and labeled. Then each tree was felled for volume measurement. Huber method was used considering measurement along stems with diameters up to $3.0 \mathrm{~cm}$. The volume of each section of stem was calculated by applying equation I and the total volume $(\mathrm{Vt})$ of the tree was obtained by the sum of volumes in each section. For commercial volume (Vc), only the sections with diameters greater than 3,0 $\mathrm{cm}$ were considered and for the last section, total volume (with diameters lower than $3,0 \mathrm{~cm}$ ) were considered the as cones, with volumes being calculated by the equation 2 , where $V_{i}$ is the volume of the $i$-th section, $V_{\text {cone }}$ is the volume of cone (last section), $g_{i}$ is the $i$-th sectional area and $L$ is the stem section length.

$$
\begin{aligned}
& V_{i}=g_{i} \cdot L \\
& V_{\text {cone }}=\frac{g_{c} \cdot L}{3}
\end{aligned}
$$




\section{Data processing}

The data obtained from the measurement of all individuals was used to train artificial neural networks and to adjust volumetric equations to estimate total and commercial volume of trees. Three situations were considered: (a) ANN training and one equation adjustment for all data; (b) ANN training and one equation adjustment for each of the species that had more occurrences; (c) ANN training considering data set from the five most abundant species and species as a categorical input.

\section{Artificial neural networks}

The artificial neural networks were training under a multilayer perceptron (MLP) structure. The used algorithm was backpropagation taking into consideration a learning rate equals to $0.00 \mathrm{I}$ and stopping criteria based on the average of square error minimization (BINOTI et al., 2014). The neurons from the hidden layer had as transfer function a hyperbolic tangent function and the one from the output layer had a sigmoidal function. Training and validation were made with NeuroForest software (BINOTI et al, 20I3).

Situations (a) and (b) considered $\mathrm{D}$ and $\mathrm{Ht}$ as input variables when estimating the total volume and $\mathrm{D}$ and $\mathrm{Hc}$ when estimating commercial volume. In these cases, 2 neurons were considered in the input layer and I neuron in the output layer. Situation (c) considered $\mathrm{D}, \mathrm{Ht}$ and specie as input variables when estimating total volume and $\mathrm{D}, \mathrm{Hc}$ and species when estimating commercial volume. In this case, 7 neurons were considered in the input layer and I neuron in the output layer. The number of neurons in the intermediary layer was defined by trial and error as overfitting was avoided by the search for a definite quantity of neurons.

In all situations, different proportions of training and validation data were evaluated. The first of them took into consideration $70 \%$ of data for training and $30 \%$ for validation and the second one took $80 \%$ of data for training and $20 \%$ for validation (DIAMANTOPOULOU; MILIOS, 20I0, BINOTI, 20I5).

\section{Regression models}

Four volumetric models were considered for this study according the literature (REZENDE et al, 2006) and previous tests that were made with the database. The equation models of Schumacher and Hall [3], Naslund [4], Meyer [5] and Spurr [6] were adjusted by usage of the ordinary least square method, where $V$ is the volume (total or commercial), in $\mathrm{m}^{3}$; $\mathrm{D}$ is the diameter at breast height in $\mathrm{cm} ; \mathrm{H}$ is total or commercial heights, in $\mathrm{m}$; and $\beta_{i}$, with $i=1, \ldots, 5$, the parameters; and $\operatorname{Ln}()$ is the Napierian logarithm.

$$
\begin{aligned}
& \operatorname{Ln}(V)=\beta_{0}+\beta_{1} \operatorname{Ln}(D)+\beta_{2} \operatorname{Ln}(H)+\varepsilon \\
& V=\beta_{0}+\beta_{1} D^{2}+\beta_{2} D^{2} H+\beta_{3} D^{2}+\beta_{4} H^{2}+\varepsilon \\
& V=\beta_{0}+\beta_{1} D+\beta_{2} D^{2}+\beta_{3} D H+\beta_{4} D^{2} H+\beta_{5} H+\varepsilon \\
& V=\beta_{0}+\beta_{1} D^{2} H+\varepsilon
\end{aligned}
$$

For results and evaluation of the trained artificial neural networks and adjusted volumetric equations, graphics of observed values versus estimated values, statistics of percentage root mean square error (RMSE) [7] and correlation coefficient between observed and estimated volume ( $r$ ) [8] were used. Values of residual standard errors $\left(\mathrm{S}_{\mathrm{yx}}\right)$ [9] and adjusted coefficients of determination $\left(\mathrm{R}_{\mathrm{adj}}{ }^{\mathrm{d}}\right)$ [10] were considered only for regression model analyses. The " $t$ " test was used for comparing the results obtained by the trained ANN and by the adjusted regression models at $5 \%$ significance, Where: cov is the covariance; $s^{2}$ is the variance; $y_{i}$ is the $\mathrm{i}$-th observed value; $\mathrm{y}^{\prime} \mathrm{i}$ is the $\mathrm{o} \mathrm{i}$-th estimated value; $\mathrm{SS}_{\text {res }}$ is the sum of squares of residuals; $\mathrm{SS}_{\text {total }}$ is the total sum of squares; $n$ is the number of observations; and $k$ is the number of parameters in the model.

$$
\begin{aligned}
& \text { RMSE\% }=\frac{100}{\frac{1}{n} \sum_{i=1}^{n}\left(y_{i}\right)} \sqrt{\frac{1}{n} \sum_{i=1}^{n}\left(y_{i}-y_{i}^{\prime}\right)^{2}} \\
& r_{y^{\prime}}=\frac{\operatorname{cov}\left(y, y^{\prime}\right)}{\sqrt{s^{2}(y) s^{2}\left(y^{\prime}\right)}} \\
& S_{y x}=\sqrt{s_{y x}^{2}} \\
& R^{2}=1-\frac{S S_{\text {res }} /(n-k)}{S S_{\text {total }} /(n-1)}
\end{aligned}
$$

\section{RESULTS AND DISCUSSION}

The sampling considered the measurement of 567 individuals distributed in 45 species and presented a small variation in $D$ and total height (Table I). The most abundant species were Heteropterys byrsonimifolia, Machaerium opacum, Terminalia fagifolia, Copaifera langsdorffii and Curatella americana. These species are commonly observed in studies about forest inventories in the Brazilian savanna, for instance, in Torres et al. (2017) and Massi et al. (2017). A value of $8.74 \mathrm{~cm}$ for diameter average and $4.5 \mathrm{~m}$ of height was obtained by Araújo et al. (2007). These area values are close to the ones from this study. 
TABLE I Descriptive analysis of the collected data.

\begin{tabular}{ccccccc}
\hline Species & Variables & $\mathrm{N}$ & Average & Max. & Min. & $\begin{array}{c}\text { Standard } \\
\text { deviation }\end{array}$ \\
\hline \multirow{2}{*}{ General } & $\mathrm{D}(\mathrm{cm})$ & 567 & 5.86 & 26.26 & $3.0 \mathrm{I}$ & 2.76 \\
& $\mathrm{Ht}(\mathrm{m})$ & 567 & 4.69 & $12.4 \mathrm{I}$ & 1.94 & 1.39 \\
\hline Copaifera & $\mathrm{D}(\mathrm{cm})$ & 30 & 8.33 & 17.83 & 3.66 & 3.47 \\
langsdorffii & $\mathrm{Ht}(\mathrm{m})$ & 30 & 6.36 & 9.90 & 3.23 & 1.75 \\
\hline Curatella & $\mathrm{D}(\mathrm{cm})$ & 30 & 7.20 & $13.8 \mathrm{I}$ & 3.85 & $2.6 \mathrm{I}$ \\
americana & $\mathrm{Ht}(\mathrm{m})$ & 30 & 4.03 & 6.25 & 1.96 & 1.18 \\
\hline Heteropterys & $\mathrm{D}(\mathrm{cm})$ & $15 \mathrm{I}$ & 4.78 & 12.89 & 3.02 & 1.49 \\
byrsonimifolia & $\mathrm{Ht}(\mathrm{m})$ & $15 \mathrm{I}$ & 4.33 & 7.45 & 2.64 & 0.93 \\
\hline Machaerium & $\mathrm{D}(\mathrm{cm})$ & 87 & 7.25 & 16.23 & 3.34 & 2.83 \\
opacum & $\mathrm{Ht}(\mathrm{m})$ & 87 & 4.27 & 9.70 & 1.94 & 1.28 \\
\hline Terminalia & $\mathrm{D}(\mathrm{cm})$ & 31 & 5.23 & 9.33 & 3.34 & 1.64 \\
fagifolia & $\mathrm{Ht}(\mathrm{m})$ & 31 & 4.70 & 6.79 & 3.30 & 0.90 \\
\hline
\end{tabular}

Schumacher and Hall and Naslund equations presented the best estimates for total volume and commercial volume, respectively, considering the situation (a) (Table 2). When analyzing situation (b), Schumacher and Hall equation stands out for total volume, presenting positive results in 6 out of 10 evaluations. The second one is Meyer's equation, that showed good results for the total volume of Terminalia fogifolia and commercial volume of Copaifera langsdorffii and Heteropterys byrsonimifolia. Spurr's equation presented the best results only for total volume estimates of Curatella americana.

These results demonstrate that evaluation of different models for each species in a forest inventory to obtain acceptable estimates is imperative. However, it can be exhaustive and time consuming, mainly if there are too many species or if species have few individuals sampled. For instance, Rezende et al. (2006) tested six models for volume estimates and Rufini et al. (2010) evaluated twelve volumetric models.

Considering the results obtained with trained artificial neural networks, it is possible to state that for all data sets the use of 5 neurons in the hidden layer was sufficient for good estimates, with no overfitting, except for the total volume estimates of Curatella americana and commercial volume of Heteropterys byrsonimifolia, (Table 3). For these, 6 neurons were necessary in the intermediate layer. This low quantity of neurons match the results obtained by Miguel et al. (2015) and can be explained by the input-variable amount in the neural network. There isn't a rule for the number of neurons in the intermediary layer, but it is important to consider that a great number of neurons may cause overfitting (HAYKIN, 2009) and a small number of neurons in the structure cannot help ANN learn the relationship pattern between input and output values.

Evaluating the proportion of data for training, in all cases the use of $70 \%$ of data for training and $30 \%$ for validation presented the best results, except with Heteropterys byrsonimifolia e Macherium opacum for which needed $80 \%$ of data for training. This proportion is associated with two different ideas: the first one is related to the amount of data for each modelling and if there is a small database. It is interesting to use a large proportion of the data for the training step. The second one is related to the fact that validation data is important for analyzing the behavior of neural network knowledge in order to avoid overfitting. In this case, validation statistics are poor, then it can be an signal that the network loses the ability to generalize equivalent input-output patterns (HAYKIN, 2009).

The estimates of total volume presented lower values of RMSE\% and larger values for coefficient correlation when considered the situation (a) for the trained ANN. This result is equivalent to the one obtained by Miguel et al (2015). The author took values that are higher than $96 \%$ with ANN presenting better results than with regression. However, Naslund's equation

TABLE 2 Results of the adjusted equations for total volume and commercial volume considering all individuals, situation (a), and individuals from each specie, situation (b).

\begin{tabular}{|c|c|c|c|c|c|c|c|c|c|c|c|}
\hline Situation & Data & Volume & Eq. & $\beta_{0}$ & $\beta_{1}$ & $\beta_{2}$ & $\beta_{3}$ & $\beta_{4}$ & $\beta_{5}$ & Syx & $\mathrm{R}_{\text {adi }}^{2}$ \\
\hline \multirow{2}{*}{ (a) } & \multirow{2}{*}{ General } & Total & (3) & $-9.394|3|$ & 2.312010 & 0.379157 & - & - & - & 42.6 & 91.98 \\
\hline & & Commercial & $(4)$ & 0.000172 & -0.000002 & 0.000035 & -0.000107 & - & - & 23.8 & 98.35 \\
\hline \multirow{10}{*}{ (b) } & Copaifera & Total & (3) & $-9.745 \mid 33$ & 2.155520 & 0.739042 & - & - & - & 10.9 & 98.40 \\
\hline & Langsdorffii & Commercial & (5) & 0.012227 & -0.003328 & 0.000174 & 0.000972 & 0.000020 & -0.00334 & 16.3 & 96.96 \\
\hline & Curatella & Total & (6) & -8.780257 & 0.865155 & - & - & - & - & 43.9 & 89.76 \\
\hline & Americana & Commercial & (3) & -8.918112 & 2.736352 & $-0.50344 I$ & - & - & - & 31.7 & 92.30 \\
\hline & Heteropterys & Total & (3) & 0.000072 & 2.057850 & 0.715326 & - & - & - & 24.2 & 94.49 \\
\hline & Byrsonimifolia & Commercial & (5) & 0.010275 & -0.004245 & 0.000536 & 0.000975 & -0.000074 & -0.002329 & 15.8 & 95.97 \\
\hline & Machaerium & Total & (3) & -9.344885 & 2.196087 & $0.47|64|$ & - & - & - & 17.6 & 97.46 \\
\hline & Opacum & Commercial & (3) & 0.000105 & I.808934 & 0.812183 & - & - & - & 12.7 & 98.64 \\
\hline & Terminalia & Total & $(5)$ & 0.016418 & -0.009845 & 0.001389 & 0.000685 & -0.000098 & -0.000191 & 11.9 & 98.20 \\
\hline & Fagifolia & Commercial & (3) & -9.858161 & 2.2973567 & 0.626322 & - & - & - & 19.0 & 97.20 \\
\hline
\end{tabular}

Eq. is the considered equation: (3) for Schumacher e Hall, (4) for Naslund, (5) for Meyer and (6) for Spurr. 

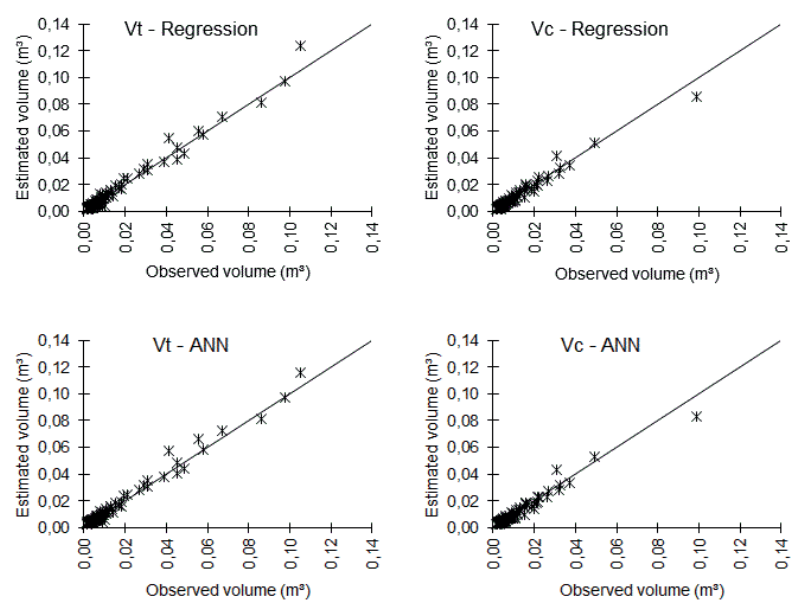

FIGURE I Graphics of observed versus estimated volume considering one ANN training and one equation adjustment for all data (situation "a") parted by volume type ( $\mathrm{t}$ is total volume and $\mathrm{Vc}$ is commercial volume).

provided a RMSE\% value about $2 \%$ lower than ANN for commercial volume estimates in this particular study.

Correlations between observed and estimated values $\left(r_{y \hat{y}}\right)$ were high for both ANN and equations of regression, independently of the output variable (total or commercial volume) (Table 3). This fact is reinforced by the graphics of observed versus estimated values (Figure I) and indicates that the variations in total and commercial volumes have been described by the $D$ and $\mathrm{H}$ (total or commercial) variables. Soares et al. (20l3) also states similarities between residual graphics of observed versus estimated volumes considering ANN and volume equation.

The $t$ test results evaluating identity methods show that both of themarestatistically different. These differences can be explained by the fact that linear regression models stablish fixed relations between variables, while ANN is more flexible for this objective. This result is different from Gorgens et al. (2009). These authors concluded that the estimates from ANN were statistically equivalent to the estimates from the Schumacher and Hall equation, when the $t$ test was applied. However, in that study, the species Eucalyptus spp. e Tectona grandis were analyzed in homogeneous plantations, conditions which correlations between diameter at breast height and height are greater than in natural forests.

Volumetric equations for Copaifera langsdorffii presented more precise estimates than ANN (Table 3), for situations (b) and (c). For Curatella americana, ANN presented greater errors for total volume estimates and the volumetric equation presented equivalent errors for commercial volume. It is still possible to positively rate the trained ANN considering species as categorical input in situation (c). Bearing in mind volume estimates for Heteropterys byrsonimifolia and Machaerium opacum, both ANN and equation presented low values of RMSE\% for total and commercial volume, respectively. The volumes estimated for Terminalia fagifolia had the best values when using ANN in the situation (b).

Özçelik et al. (2010) found values of RMSE\% varying between $4.67 \%$ and $14.88 \%$, lower than those obtained in this study (Table 3). This difference can be associated to the irregularity of stem shapes from the Brazilian savanna species. This characteristic imposes a high variation on the patterns of relation among diameter, height and volume variables.

The estimates of volume (total and commercial) for the Copaifera langsdorffii, presented a small dispersion around the $45^{\circ}$ line in the graphics comparing estimated values and observed values for all situations and methods, except in the case which ANN was applied for commercial volume in the situation (c) (Figure 2). Analyzing the results for Curatella americana, ANN in situation (b) presented a larger dispersion for total volume (Figure 3) what generated a greater value of $\mathrm{RMSE}_{\%}$.

TABLE 3 Values of the statistics for analysis of quality of estimates from regression models and artificial neural networks.

\begin{tabular}{|c|c|c|c|c|c|c|c|c|c|c|c|c|}
\hline \multirow[b]{2}{*}{ Data } & \multirow[b]{2}{*}{ Volume } & \multicolumn{3}{|c|}{ Regression } & \multicolumn{4}{|c|}{ ANN Situation (b) } & \multicolumn{4}{|c|}{ ANN Situation (c) } \\
\hline & & Eq. & $\begin{array}{c}\text { RMSE } \\
\%\end{array}$ & ryy' & Arc. & Train & $\begin{array}{c}\text { RMSE } \\
\%\end{array}$ & $r_{y y^{\prime}}$ & Arc. & Train & $\begin{array}{c}\text { RMSE } \\
\%\end{array}$ & ryy' \\
\hline General & $\begin{array}{c}\text { Total } \\
\text { Commercial }\end{array}$ & $\begin{array}{l}(3) \\
(4)\end{array}$ & $\begin{array}{l}22.88 \\
23.02 \\
\end{array}$ & $\begin{array}{l}98.11 \\
97.39 \\
\end{array}$ & $\begin{array}{l}2-5-1 \\
2-5-1\end{array}$ & $\begin{array}{l}70 \\
70 \\
\end{array}$ & $\begin{array}{l}21.64 \\
25.56 \\
\end{array}$ & $\begin{array}{l}98.21 \\
97.09 \\
\end{array}$ & \multirow{11}{*}{$3-5-1$} & \multirow{11}{*}{70} & - & $\begin{array}{l}- \\
-\end{array}$ \\
\hline Copaifera & Total & (3) & 26.02 & 86.79 & $2-5-1$ & 70 & 28.47 & 85.95 & & & 26.98 & 86.51 \\
\hline langsdorffii & Commercial & (5) & 10.54 & 84.63 & $2-5-1$ & 70 & 23.38 & 83.61 & & & 29.23 & 79.41 \\
\hline Curatella & Total & (6) & 23.41 & 88.94 & $2-6-1$ & 70 & 67.12 & 78.27 & & & 21.75 & 88.19 \\
\hline americana & Commercial & (3) & 52.92 & 86.20 & $2-5-1$ & 70 & 18.47 & 87.14 & & & 15.67 & 87.36 \\
\hline Heteropterys & Total & (3) & 54.70 & 91.45 & $2-5-1$ & 80 & 53.98 & 92.38 & & & 54.23 & 93.01 \\
\hline byrsonimifolia & Commercial & (5) & 20.97 & 93.21 & $2-6-1$ & 80 & 21.12 & 92.71 & & & 21.94 & 92.30 \\
\hline Machaerium & Total & (3) & 19.39 & 93.95 & $2-5-1$ & 80 & 16.08 & 94.03 & & & 18.99 & 93.59 \\
\hline opacum & Commercial & (3) & 17.95 & 94.13 & $2-5-1$ & 80 & 18.56 & 93.20 & & & 24.18 & 91.93 \\
\hline Terminalia & Total & (5) & 35.05 & 86.72 & $2-5-1$ & 70 & 21.94 & 89.14 & & & 42.23 & 85.49 \\
\hline fagifolia & Commercial & (3) & 29.70 & 88.56 & $2-5-1$ & 70 & 20.55 & 89.99 & & & 31.42 & 86.42 \\
\hline
\end{tabular}

Eq. is the considered equation, Arc. is ANN's architecture and Train is the proportion of the data used for ANN's training process, RMSE\% is root mean square error, $r$ is correlation coefficient. 


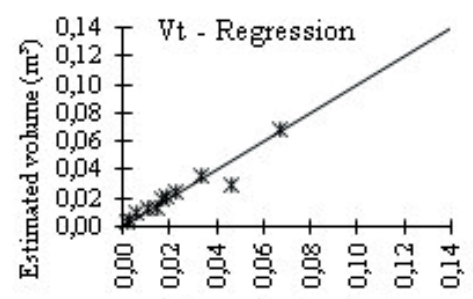

Observed vohume $\left(\mathrm{m}^{5}\right)$

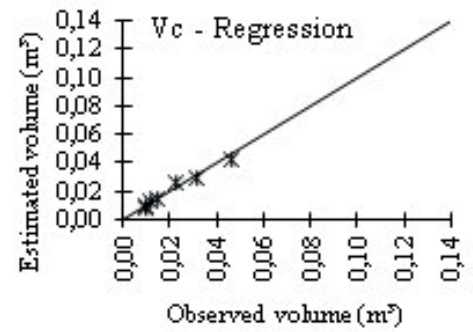

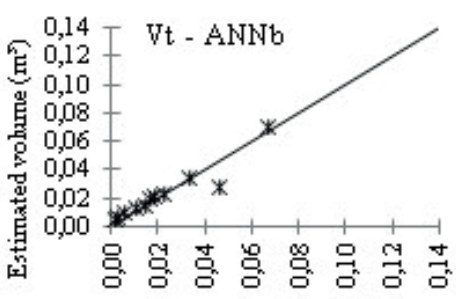

Observed vohume $\left(\mathrm{m}^{5}\right)$

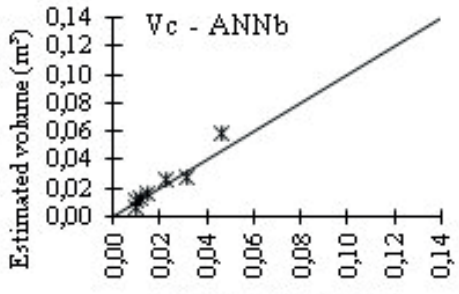

Observed vohume $\left(\mathrm{m}^{5}\right)$

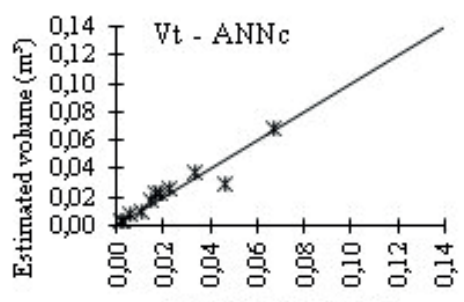

Observed vohume $\left(\mathrm{m}^{5}\right)$

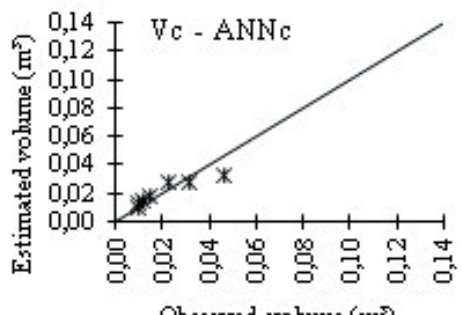

FIGURE 2 Graphics of observed volume versus estimated volume considering the three situations evaluated for Copaifera langsdorffii.

There was an underestimation of total volume and commercial volume estimates for the biggest trees of Heteropterys byrsonimifolia in both methods (Figure 4). Considering the species Machaerium opacum (Figure 5) and Terminalia fagifolia (Figure 6), there was similarity between $\mathrm{ANN}$ and equations.

The " $\mathrm{t}$ " test evidenced statistical equivalence between equations' estimates and ANN for situation (c), for all volume data, except for total volume of Curatella americana, Heteropterys byrsonimifolia and Terminalia fagifolia. Equations and ANN for the situation (b) were statistically equivalent for total volume of Heteropterys byrsonimifolia and Machaerium opacum.

Results showed that artificial neural networks can generate estimated values that are close or better than the ones provided by volumetric equations. ANN in situation (c) was efficient in estimating the volumes and their use is preferable in a practical way as a unique trained ANN can calculate total volumes or commercial volumes for all species.
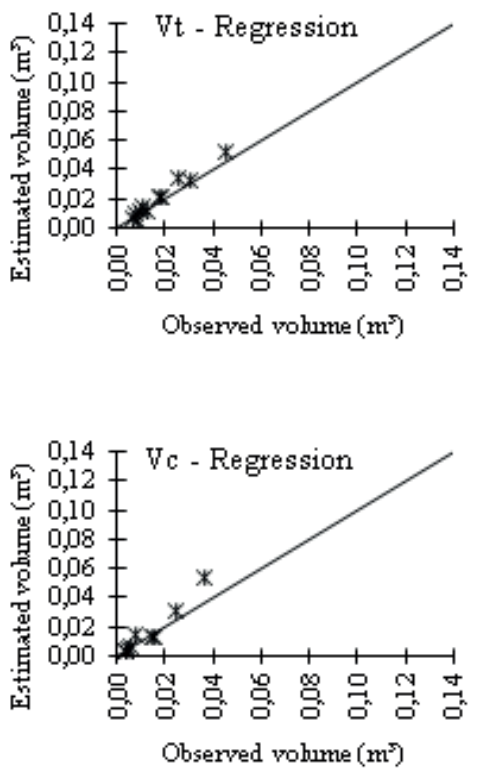
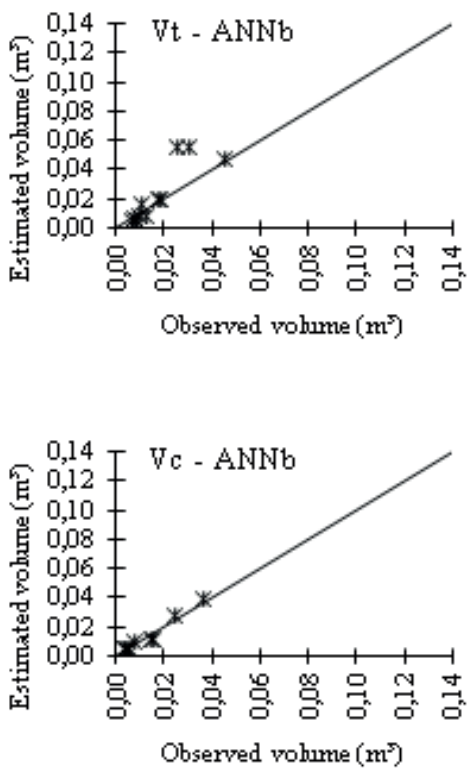
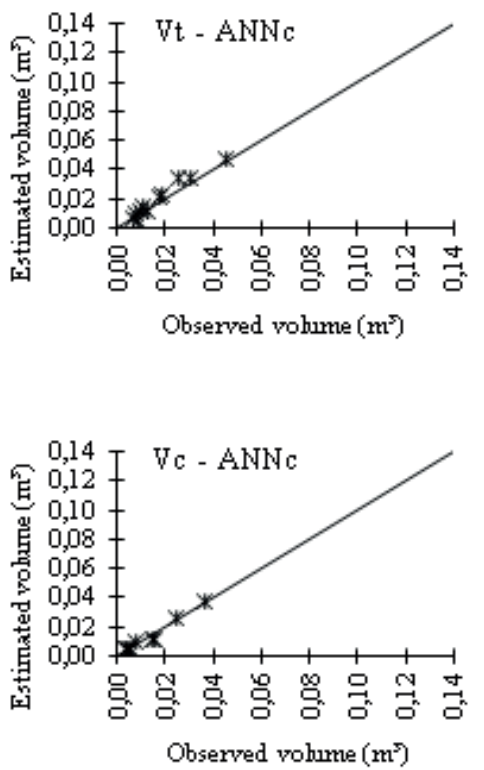

FIGURE 3 Graphics of observed volume versus estimated volume considering the three situations evaluated for Curatella americana. 

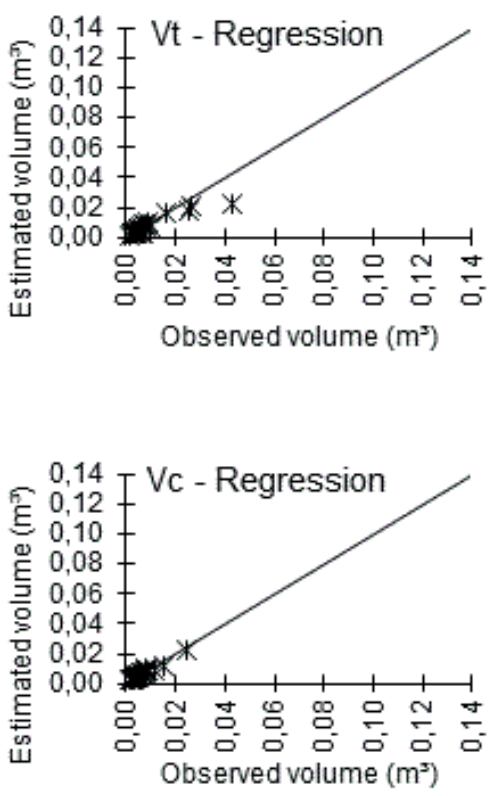
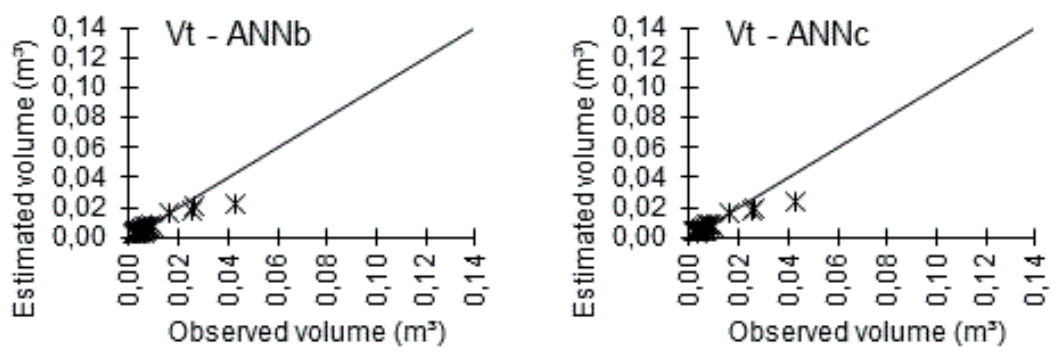

FIGURE 4 Graphics of observed volume versus estimated volume considering the three situations evaluated for the specie Heteropterys byrsonimifolia.
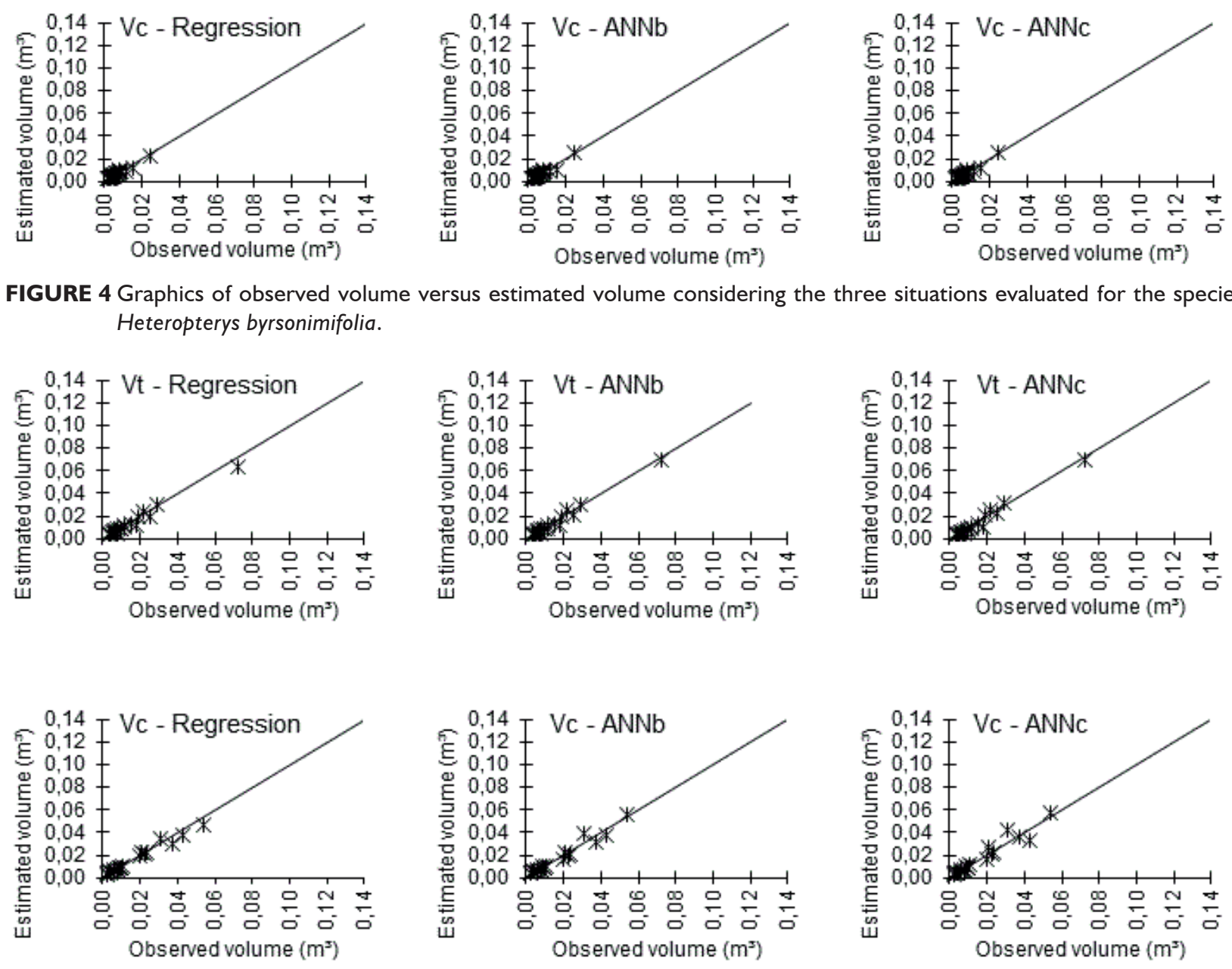

FIGURE 5 Graphics of observed volume versus estimated volume considering the three situations evaluated for Machaerium opacum.

\section{CONCLUSION}

This study has found that artificial neural networks can be efficient to estimate total and commercial tree volumes from the Brazilian savanna. Artificial neural networks that consider species as a categorical input variable and that are data trained present better results than the ones trained for each species in separate, without categorical input. Both ANN and regression models are efficient in obtaining estimated volumes of trees in the Brazilian savanna.

\section{REFERENCES}

ARAÚJO, E. J. G.; SOUZA, F. N.; SCOLFORO, J. R. S.; MELLO, J. M.; SILVA, C. P. C. Diversidade e estrutura de seis fragmentos de cerrado stricto sensu no extremo norte de Minas Gerais. Revista Brasileira de Biociência, v. 5, p. 546-548, 2007.

BINOTI, D. H. B.; BINOTI, M. L. M. S.; LEITE, H. G. BR Patent No 13410-5. Brasil: Instituto Nacional da Propriedade Industrial, 2013. 

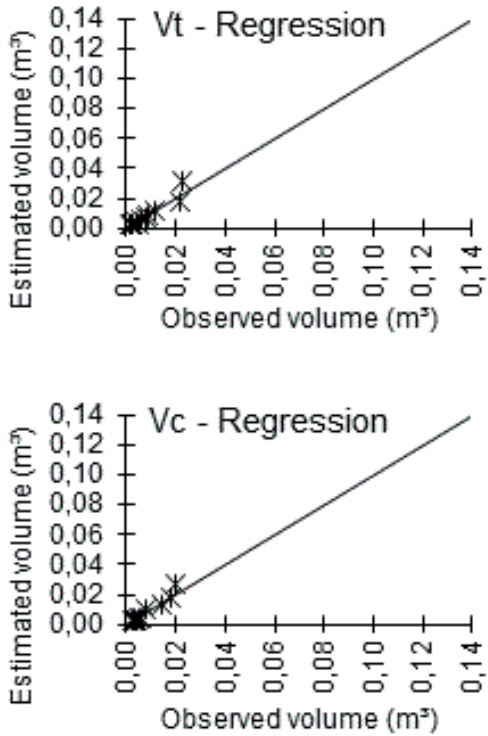
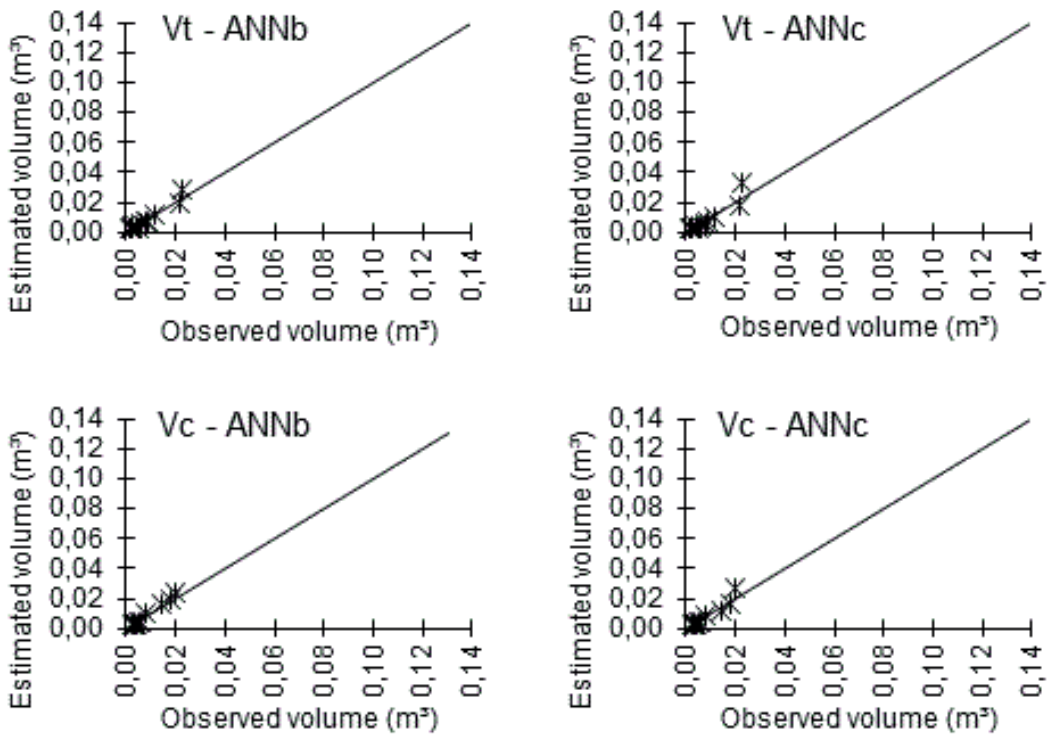

FIGURE 6 Graphics of observed volume versus estimated volume considering the three situations evaluated for Terminalia fagifolia.

BINOTI, M. L. M. S.; BINOTI, D. H. B.; LEITE, H. G. Aplicação de redes neurais artificias para estimação da altura. Revista Árvore, v. 37, n. 4, p. 639-645, 2013.

BINOTI, D. H. B.; BINOTI, M. L. M. S.; LEITE H. G. Configuração de redes neurais artificiais para estimação do volume de árvores. Ciência da Madeira, v. 5, p. 58-67, 2014.

BINOTI, M. L. M. S.; LEITE, H. G.; BINOTI, D. H. B.; GLERIANI, J. M. Prognose em nível de povoamento de clone de eucalipto empregando redes neurais artificiais. Cerne, v. 2I, n. I, p. 97-105, 2015.

BRAGA, A. P.; CARVALHO, A. C. P. L. F.; LUDERMIR, T. B. Redes Neurais Artificiais: teoria e aplicações. Livros técnicos e científicos editora S.A, 2000. 262p.

CAMPOS, B. P. F; SILVA, G. F; BINOTI, D. H. B; MENDONÇA, A. R; LEITE, H. G. Predição da altura total de árvores em plantios de diferentes espécies por meio de redes neurais artificiais. Pesquisa Florestal Brasileira, v. 36, n.88, p.375-385, 2016.

DIAMANTOPOULOU, M. J.; MILIOS, E. Modelling total volume of dominant pine trees in reforestations via multivariate analysis and artificial neural network models. Biosystems Engineering, v. 105, n.3, p. 306-315, 2010.

GORGENS, E. B.; LEITE, H. G.; SANTOS, H. N.; GLERIANI, J. M. Estimação do volume de árvores utilizando redes neurais artificiais. Revista Árvore, Viçosa, v. 33, n. 6, p. I|4I-I|47, 2009.

HAYKIN, S. Neural networks and learning machines. 3 ed. Pearson, 2009. 906p.

HUSCH, B.; BEERS, T. W.; KERSHAW JR., J. A. Forest mensuration. John Wiley \& Sons, 2002. 456p.
JAIN, A. K.; MAO, J.; MOHIUDDINN, K. M. Artificial Neural Networks: A Tutorial. Computer, v. 29, p. 31-44, 1996.

KLINK, C. A; MACHADO, R. B. A conservação do Cerrado brasileiro. Megadiversidade, v. I, n. I, p. I47-I55, 2005.

MASSI, K. G.; EUGÊNIO, C. U. O; FRANCO, A. C. Post-fire reproduction of herbs at a savanna-gallery forest boundary in Distrito Federal, Brazil. Brazilian Journal of Biology, v. 77, n. I, p. 876-886, 2017.

MIGUEL, E. P.; MOTA, F. C. M.; TEO, S. J.; NASCIMENTO, R. G. M.; LEAL, F. A.; PEREIRA, R. S.; REZENDE, A. V. Artificial intelligence tools in predicting the volume of trees within a forest stand. African Journal of Agricultural Research, v. II, n. 2I, p. 1914-1923, 2016.

MIGUEL, E.P; REZENDE, A.V.; LEAL, F.A.; MATRICARDI, E.A.T.; VALE, A.T.; PEREIRA, R.S. Redes neurais artificiais para a modelagem do volume de madeira e biomassa do cerradão com dados de satélite. Pesquisa Agropecuária Brasileira, v. 50, n. 9, p. 829-839, 2015.

NUNES, M. H.; GORGENS, E. B. Artificial intelligence procedures for tree taper estimation within a complex vegetation mosaic in Brazil. PLOS ONE, v. II, n. 5, p. I-I6, 2016.

ÖZÇELIK, R.; DIAMANTOPOULOU, M. J.; BROOKS, J. R.; WIANT JR, H. V. Estimating tree bole volume using artificial neural network models for four species in Turkey. Journal of Environmental Management, v.9I, p. 742-753, 2010.

REZENDE, A. V; VALE, A. T.; SANQUETTA, C. R.; FIGUEIREDO FILHO, A.; FELFILI, J. M. Comparação de modelos matemáticos para estimativa do volume, biomassa e estoque de carbono da vegetação lenhosa de um cerrado sensu stricto em Brasília, DF. Scientia Forestalis, v.7I, p. 65-76, 2006. 
RUFINI, A.L; SCOLFORO, J.R.S; OLIVEIRA, A.D; MELLO, J.M. Equações volumétricas para o cerrado sensu stricto, em Minas Gerais. CERNE, v. 16, p. I-II, 2010.

SILVA, M. L. M.; BINOTI, D. H. B.; GLERIANI, J. M.; LEITE, H. G. Ajuste do modelo de Schumacher e Hall e aplicação de redes neurais artificiais para estimar volume de árvores de eucalipto. Revista Árvore, v. 33, n.6, p. I | 33- I 139, 2009.

SOARES, F. A. A. M. N. Predição recursiva de diâmetro de clones de eucalipto utilizando rede perceptron de múltiplas camadas para o cálculo de volume. 2012. |3|p. Tese (Doutorado em Engenharias). Universidade Federal de Uberlândia, Uberlândia, 2012.
SOARES, F. A. A. M. N.; FLÔRES, E. L.; CABACINHA, C. D.; CARRIJO, G. A.; VEIGA, A. C. P. Recursive diameter prediction and volume calculation of eucalyptus trees using Multilayer Perceptron Networks. Computers and Electronics in Agriculture, v.78, n. I,p. 19-27, 201 I.

SOARES, F. A. A. M. N.; FLÔRES, E. L.; CABACINHA, C. D.; CARRIJO, G. A.; VEIGA, A. C. P. Recursive diameter prediction for calculating merchantable volume of eucalyptus clones using Multilayer Perceptron. Neural Computing and Applications, v. 22, n. 7, p. 1407-1418, 2013.

TORRES, D. M.; FONTES, M. A. L.; SAMSONAS, H. P. Relações solo-vegetação na estruturação de comunidades de cerrado sensu stricto no sul de Minas Gerais, Brasil. Rodriguésia, v. 68, n. I, p. II5-128, 2017. 